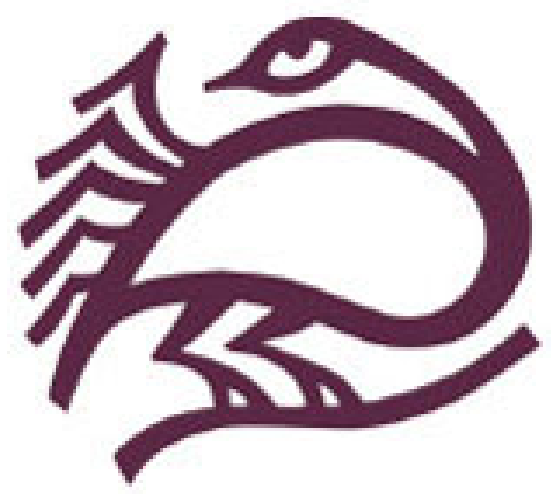

Post-Zionist Critique on Israel and the Palestinians: Part I: The Academic Debate Author(s): Ilan Pappe

Source: Journal of Palestine Studies, Vol. 26, No. 2 (Winter, 1997), pp. 29-41

Published by: University of California Press on behalf of the Institute for Palestine Studies

Stable URL: http://www.jstor.org/stable/2537781

Accessed: 28/03/2014 10:32

Your use of the JSTOR archive indicates your acceptance of the Terms \& Conditions of Use, available at http://www.jstor.org/page/info/about/policies/terms.jsp

JSTOR is a not-for-profit service that helps scholars, researchers, and students discover, use, and build upon a wide range of content in a trusted digital archive. We use information technology and tools to increase productivity and facilitate new forms of scholarship. For more information about JSTOR, please contact support@ jstor.org. 


\title{
Post-Zionist Critique on Israel and the Palestinians \\ Part I: The Academic Debate
}

\author{
ILAN PAPPÉ
}

This three-part article describes changes in how Israelis-scholars, writers, poets, film makers, and others on Israel's cultural scene-view themselves and the "Other." Part I presents the scholarly debate on Israel's past and present that laid the groundwork for the transformation of the cultural discourse described in the second and third parts. The debate, launched by new findings in the Israeli archives and encouraged by an ideology critical of Zionism, also was influenced by sociopolitical and economic changes in Israeli society in the wake of the October 1973 war. The various aspects of the post-Zionist critique-the challenge by the "new historians" and "critical sociologists" not only of the Zionist interpretation but also of the role of Israeli academia in providing the scholarly underpinnings of this interpretation-are examined.

DURING THE LAST DECADE, Israeli universities have become the venue for a lively debate on Israeli history and sociology. Lately, the debate has been transferred to the public arena through articles in the mainstream press and even has been treated in the broadcast mass media. Moreover, a look at other cultural arenas and media reveals that the debate has extended beyond academia into the artsfilms, poetry, and literature. The most obvious characteristic of this debate is the willingness of a considerable number of Israeli Jews to reassess the way the "Arab" is perceived and treated in past and present Israel. It should be mentioned, however, that the debate has not attracted anyone beyond the "chattering and writing classes" of Israeli society; it is an elitist exercise, albeit with wide implications for the society as a whole.

The academic debate in Israel about Zionism began in the 1980s with the appearance of a number of scholarly works presenting images of past and present Jewish society in Palestine that were strongly at odds with the Israeli public's self-image and collective memory. The works challenged the most sacred "truths" of Zionism and questioned their validity for the present generation. The authors of these works also criticized the role played by the country's academic institutions in shaping the Zionist self-image and the Zionist interpretation of the Palestine reality. Directly and indirectly, they deconstructed the works of those

Ilan Pappé, professor of political science at Haifa University and academic head of the Institute for Peace Research Givat Haviva, is the author of The Making of the Arab-Israeli Conflict, 1947-1951, among other works. 
who dominated Israeli academic writing on Palestine's history and contemporary Jewish society.

These scholars have been in the public consciousness long enough to be regarded as a cultural phenomenon in Israel. The local press calls them the "postZionist" scholars, a term not all of these scholars accept. ${ }^{1}$ Nonetheless, as this is a handy concept for describing the essence of what they are doing, we shall apply it broadly in this article not only to all those who have revised or criticized the work of the mainstream Zionist academic community in Israel but also to artists, novelists, and others using a new cultural discourse.

The term post-Zionism is a hybrid of anti-Zionist notions and a postmodernist perception of reality. It has become a convenient term that groups together Zionist and anti-Zionist Jews in Israeli academia and politics. In the scholarly world, the terms anti-Zionist and Zionist are largely a matter of self-definition: Among this group, the works of those who declare themselves Zionist are generally as antagonistic toward Zionism as those of authors openly calling themselves antiZionist. It is important to note that the "post-Zionist" scholars or "new historians" or "new sociologists" are not the first to challenge the Zionist version of Israel's past and present. Their precursors, however, were mostly on the left, members of the communist party or fringe groups such as MAPAM. The ideological orientation of these last, coupled with the fact that they were not historians or sociologists by profession (Israel Shahak and Benny Beit-Hallahmi, for example, are professors of chemistry and psychology, respectively), made it easy to dismiss their findings as mere claims of political activists beyond the pale of the national consensus. In contrast, the "new historians" and "new sociologists," as scholars accredited by official academia to research and teach the country's past, were the first to challenge the conventional thinking from within the system.

As for the "postmodernist" part of the equation, it derives from the tendency among some of the group to view the present situation in Israel as a phase in which most of the Zionist truths have collapsed but there is no sign of what would replace them. Thus, to borrow postmodernist discourse, they have deconstructed the reality but are unable to reconstruct it. Some of these scholars become more confident about the future when they envisage the creation of an Israeli rather than a Jewish state: a state for all its citizens. Most, however, confine their assessment of the future to a long civil and cultural war between the various components polarizing and composing Israeli society.

Chronologically, the postmodernist critique appeared only after the debate on the 1948 war had erupted-a debate that was purely positivist in nature and did not involve any serious metahistorical or theoretical discussion. Hence, we begin our survey with the "new history" of the 1948 war.

\section{The Positivist Challenge: The "New Historians"}

Mainstream Zionist historiography in Israel continues to subscribe to an impossible combination of positivist and ideological approaches to history: The facts, based on archival material, are employed to prove the moral validity of the 
Zionist claims. The positivist approach means that those researching the country's past and present ignore methodological or theoretical questions that might affect their confidence in the scientific truth of Zionism. Moreover, their research is pure elite analysis-the deeds of the elite are documented in the archives and their version of events is taken as an objective and truthful description of fact. This mixture of ideological paradigm, scholarly ethnocentricity, and empirical bookkeeping did not begin to be challenged until the 1970s with the revisionist historiography of the 1948 war, the memory of which still shapes the Israeli selfimage and national myths.

Before the appearance of the new works, the 1948 war and the Mandatory period as a whole were treated exclusively within the university departments teaching Zionist history. For these departments, the events of 1948 were the culmination of the teleological process of redemption and renaissance of the Jewish people. The role of the historian was limited to reconstructing this miracle that had begun with the awakening of the national movement in the $1880 \mathrm{~s}$ and ended with the 1948 "war of liberation" against the British. It should be noted that the Israeli terminology of the war is constructed carefully so as to confer upon Zionism the equivalent status of a third world liberation movement-hence a war against the Arabs cannot be mentioned in this context. Indeed, the two terms used for the 1948 war do not indicate any direct conflict with the Arabs: "independence" from the British (Azma'ut) and "liberation" from the yoke of the Diaspora (Shihrur).

This does not mean, of course, that the "Arabs" do not appear in Zionist historiography of the $1948 \mathrm{war}$. When the story of the 1948 war or the preceding years of the Mandate is told, researched, or taught, the Arab side is mentioned as yet another hardship with which the Jews had to cope. The message throughout the story is clear: The Jews in Palestine won against all odds. The imbalance they describe between the few Jews and the many Arabs was never so clear as in 1948 when, according to their version, the community, consisting of many Holocaust survivors who could barely fight, was faced with a hostile British government and a united Arab world preparing for a war of annihilation. The victory as presented in the traditional historiography was miraculous and was won thanks to the ingenuity of David Ben-Gurion and the heroism of the soldiers on the ground. The historians were left with the task of recreating this heroism on the battlefield while analyzing the tactical decisions taken at that and other junctures. $^{2}$

The task of describing and analyzing the Arab side of the story was entrusted to the Israeli orientalist establishment. On the whole the orientalist scholars were more neutral in their research than their colleagues in the "Jewish departments," but most of them seemed not to be interested in the Palestinians or the 1948 war. Even the most prominent among them, Yehoshua Porath, who provided the first balanced Israeli view of the Palestinians, never wrote about 1948; while he mined the archives until the year 1939, he lost interest and sympathy in his next academic works. ${ }^{3}$ The few Israeli orientalists who did write about the 1948 war avoided dealing with the nakba as a human or national tragedy and showed no 
understanding of its significance for the Palestinian side. ${ }^{4}$ Instead, they focused on the political and military maneuvering in the Arab world outside Palestine before and after the war. Similarly, when more recent generations of orientalists dealt with the PLO, they did not (with the notable exception of Moshe Shemesh) take 1948 as a starting point. The Palestinians of 1948 were erased from the academic scene in Israel. ${ }^{5}$

The absence of the Palestinian tragedy from the Israeli historical account was indicative of a more general Israeli orientalist view. The historiographical view of the Palestinians up to the 1980s was monolithic and based on stereotyping. The local population in the late Ottoman period was mentioned only in passing as a marginal component in the geographical panorama of the promised and empty land waiting to be redeemed. From 1948 until 1967, the Palestinians mostly were ignored as an academic subject matter: here and there they were mentioned as refugees. Since 1967, they have been depicted as terrorists and a threat, though not an existential one. But even in this portrayal, the Palestinians have not been granted an independent role, being shown instead as pawns within an all-Arab conspiracy to annihilate the Jewish state. There was a reason for this: Recognition of an independent (even if small and weak) national group fighting for its rights would contradict the Zionist self-image of underdog or the Zionist myth of the "few who had miraculously beaten the many." The heroic Zionist story of 1948 also would be in grave danger if another Zionist claim-that the Palestinians fled and did not fight-were to be integrated into it. If the Palestinians ran without fighting, then what was so heroic about 1948? And even if the story told is not of Palestinian heroism, it still would be one of Palestinian tragedy. The best way to deal with this predicament, academically, was simply not to deal with the Palestinian side of the story and, if possible, not to deal with 1948 at all.

The first notable change in this situation occurred when some Israeli academics became willing to treat 1948 as a subject matter, analyzing both sides of the story and not shrinking from viewing critically the behavior of all concerned in the conflict. The result was a historiographical picture very different from the one that continues to be conveyed in the educational and cultural systems in Israel. The new picture adopts major chapters in the Palestinian historiographical narrative, but also adds elements of its own.

The new portrayal was made possible by the opening of the archives dealing with the 1948 war following the thirty-year rule of declassification in Israel, Britain, and the United States. But the scholars who delved into the archives also were guided by a post-Zionist ideology and perception. In Israel, the research took place in the decade following the 1978 declassification-in other words, it took place during the Lebanon war and the intifada. Indeed, the nonconsensual war in Lebanon and the Palestinian uprising created a clear-cut distinction between Israel's peace-orientated camp and the insular expansionist "national" camp (as the Likud has defined its political bloc). Thus, the scholars who went through the newly declassified material did so after their confidence in their country's conduct already had been shaken. 
Moreover, the intifada opened a new chapter in the Israeli-Palestinian dialogue, conducted mainly by scholars. Surprising as this may sound, this dialogue acquainted most of the Israeli scholars writing about their country's past who were not connected to radical political groups with the historical version of their Palestinian academic counterparts for the first time. For many of them, this encounter brought the first recognition of the scholarly merit of what hitherto had been regarded as sheer propaganda. Unpleasant and at times shocking chapters in the Israeli historical narrative were exposed. Above all, Israeli scholars became aware of the basic contradiction between Zionist national ambitions and their implementation at the expense of the local population in Palestine. Finally, the articulation of a clear national sense of iden-

For many Israeli scholars, the postintifada dialogue brought the first recognition of the scholarly merit of what had hitherto been regarded as sheer propaganda. tity among the Israeli Palestinians, who played a crucial role in reminding the public of the existence of a counternarrative, helped to shape the "post-Zionist" agenda of Israeli academia as well. In some cases, the recognition of the other side of the story, to the point even of adopting it as the true side of the story, was the result of a certain ideological stance; in others it was the consequences of adopting a postmodern multinarrative approach to history, and in still others it was both.

The challengers became known as the "new historians" after a term coined by one of them, Benny Morris. ${ }^{6}$ But this term, borrowed from the "new history" in Europe, was misleading. The "new history" in Europe was an interdisciplinary effort to place diplomatic and elite history in a wider social and nonelite perspective. The Israeli "new historians," in contrast, dealt only with elite analysis of politics and, like their mainstream predecessors, adhered to a positivist methodology. For this reason, they more aptly should be described as revisionists, in the manner of the revisionist school in the American historiography on the cold war.

Taken together, the works of the "new historians" undermine the Zionist claim that the Jewish community in Palestine was in danger of annihilation on the eve of the 1948 war. The works describe a fragmented Arab world unable to support the inferior paramilitary Palestinian groups in their battle for postMandatory Palestine. They show how, when the Arab League eventually sent forces to the battlefield on 14 May 1948, they were not more numerous than the Israeli troops and also were poorly trained and considerably inferior in their operational capabilities on the ground. ${ }^{7}$ They demonstrate that an important factor explaining the Jewish success on the battlefield was the tacit understanding the Jewish Agency had with Transjordan whereby the Hashimites, in return for their promise not to enter the Jewish state, were allowed to take over the West Bank without a single shot being fired. ${ }^{8}$ Jewish success on the diplomatic front was attributed to a rare cooperation between the two warring superpowers in 1947 , with each for its own reasons supporting the Zionist cause against the Palestinian. Generally speaking, the Zionists succeeded in persuading large segments of world public opinion to link the Zionist cause with the Holocaust. Against such a 
claim, even able Palestinian diplomats-and there were not many in those dayshardly could win the diplomatic game. Britain, for its part, joined the general global trend, and in February 1948 even decided to support a Jewish-Hashimite understanding to divide post-Mandatory Palestine between themselves at the expense of the Palestinians.?

The "new history" also challenges the Israeli myth of the voluntary exodus of Palestinians from Palestine. Benny Morris was the first to argue, on the basis of the newly declassified documents, that many of the Palestinians had been expelled-although he did not accept the Palestinian historiographical claim, first made by Walid Khalidi in 1961, that the expulsion was part of a master plan. ${ }^{10}$ This difference of opinion shows that there is still a gap between the Palestinian national narrative and the "new history."11

One chapter in the "new history" version that is absent from the Palestinian narrative is the claim that there was a genuine willingness on the part of most of the Arab governments and what was left of the Palestinian leadership to negotiate a settlement over Palestine after the war based on Arab acceptance of the 1947 partition recommendation and the repatriation of the refugees. Israel is shown by the "new historians" as an intransigent and belligerent country unwilling to compromise or even give peace a chance (they single out the foreign minister, Moshe Sharret, as the only one willing to exhaust the opportunity for peace opened after the war). ${ }^{12}$

The "new historians" thus drew, in a pure positivist manner, what they believe was the true nature of the Israeli behavior, or rather misbehavior, toward the Arab world and the Palestinians in 1948. They drew a picture most Israelis were not aware of, a picture that provoked angry reactions from public figures and press commentators. Israeli policy before 1967 never before was depicted as aggressive, to say nothing of being at times brutal and inhuman and quite often morally unjustifiable. Although none of the "new historians" dealt with the Israeli academia in their works, once the debate became public they openly blamed the mainstream academia for concealing from the public these unpleasant chapters in the story of 1948 .

\section{Fundamental Critique of Zionism: The New Sociologists}

The research carried out during the 1980s on 1948 paved the way for a more fundamental criticism of Zionism and its role in the Israeli academia. More accurately, the new research-or the press and media coverage of it-made it possible for trends that in fact had begun earlier to register on the public consciousness. Indeed, a new readiness to look into the essence of Zionism had been triggered by the 1973 war, which caused the first cracks in Israel's wall of moral smugness and self-satisfaction. More importantly, in the relative calm that followed that war, tensions between Israel's multicultural and multiethnic fabric on the one hand and the "melting pot" ideal of the founding fathers on the other came to the fore. Social and cultural undercurrents of dissatisfaction and antagonism in Israeli society erupted in the early 1970s into a social protest against the 
evils inflicted by the state on the deprived Jewish communities, mostly North African in origin. Young and vociferous activists tried to emulate the dissent voiced by African Americans and established in the early 1970s their own Black Panther movement. The movement represented a social demand for a new and fairer distribution of the economic resources of the country and a share in the definition of its cultural identity. The protesters failed to move the Israeli Left but attracted the attention of the Right, which skillfully manipulated their protest into a mass movement that brought Menachem Begin to power in 1977. The Israeli Left lost its natural constituency, but some of its adherents in academia began to delve into the movement's causes.

The Sephardic protest movement was an internal social affair, and as such it engaged the interest of sociologists. These last not only sought to reconstruct Israel's early history, but also were intrigued by the theoretical and methodological implications of the development of a social protest movement in Israel. The Sephardic social protest movement coincided with a growing sense of national confidence among the Palestinians in Israel, and their case fortified the cases of others who felt excluded from the Zionist historical narrative and whose chronicles had been distorted in schools and university curricula.

From the late 1970s onward, academics, with the help of historical or sociological research, represented the causes of all the deprived groups as scientifically valid. They were less successful as political agents of change in Israel: Their attempt to tie together, as they had in their research, the plight of Palestinians, Sephardic Jews, and women (as a minority group) so as to create a joint political front proved to be a total failure. It remained, nonetheless, a popular vision for the more hopeful members of the academic protest movement. These developments matured after the 1982 Lebanon war. The public debate about that war seemed to encourage novelists, film makers, playwrights, musicians, poets, artists, and journalists jointly to construct a non-Zionist interpretation of the past and present reality.

The sociologists' challenge, inspired by global and theoretical developments in the humanities, was more relativist and postmodernist in nature. It reflected the disenchantment characteristic of many Western academics with the fallacies and illusions created by "enlightenment," "modernity," and other Western concepts signifying the triumph of science and logic over "uncivilized" notions from the non-Western world. The challengers here adopted the more skeptical approach to truth and data, particularly truth and data represented within a national context by the elite and the court academicians serving it. ${ }^{13}$ Israeli academia is an integral part of Western academia

Israel's new sociologists came even closer to the Palestinian narrative than the new historians had. and it thus is not surprising that Israeli historians and sociologists adopted the same interdisciplinary, skeptical, and subjective view toward their own history. It allowed them, as academics, to represent the Palestinian, the Sephardic, and the feminist side of the story, much as American scholars wished to represent the multicultural reality of their own society. 
The "new sociologists," so to speak, were not critical of their predecessors' work solely on the basis of the "facts" they presented. They also felt the need to reassess the basic paradigms these scholars employed. They pointed to a contradiction between the mainstream Israeli scholars' contribution to nation building and the university's mandate to promote pluralized and critical research. The "new sociologists" were a more diverse group than the historians. Some were more relativist, some were more anti-Zionist. Probably for the sake of convenience, the sociologist Uri Ram labeled them "post-Zionists." ${ }^{14}$

Common to all these challenges was the underlying assumption that collective memory officially was constructed through the educational system and the media. This assumption began to be voiced in the early 1970s at Haifa University, where Israel's mainstream sociologists were accused of employing methodologies that suited the Zionist ideological claims on the land and the Jewish people. ${ }^{15}$ The trend continued in the early 1980s, with more established sociologists, such as Baruch Kimmerling and Yonathan Shapiro, exposing, via domination and co-optation theories, the dictatorial and arbitrary nature of the Jewish political system that developed during the Mandatory period. ${ }^{16}$ These works challenged the myth adopted by Israeli historians of Zionism that their leaders' actions had been motivated by altruistic socialist and liberal ideologies-as still is claimed by the leading historians of Zionism in Israel today. ${ }^{17}$

The most significant contribution to the new way of thinking, however, was the application of a colonialist perspective to the historical study of Zionism. In this, Israel's new sociologists came even closer to the Palestinian narrative than the new historians had. The theoretical perspective allowed them to look at $\mathrm{Zi}$ onism as a colonialist movement without being accused of adopting unvarnished the Palestinian discourse. ${ }^{18}$ Gershon Shafir reconstructed early Zionism-despite such particularisms as the absence of a proper mother country, the marginal role played by capitalist profit and loss considerations, and the movement's nationalist discourse and motivation-as a typical colonialist movement in a colonialist era. ${ }^{19}$ Others followed suit, employing theories and methodologies hitherto ignored by their peers that substituted and substantiated a more blunt ideological claim.

\section{The New Wave of Criticism}

Following these works, the next wave of scholars opted to deal not only with history and sociology but also with metahistorical and theoretical questions. Therefore, they wrote not only about the past and the official historiography, but also about mainstream academia's reactions to the "new history." They were impressed by the harshness of the reactions, and indeed, the reactions had been harsh. Two of the most prominent Israeli scholars condemned the challenge as signifying the end of academic discourse in Israel altogether. ${ }^{20}$ At that stage, one can note a growing tendency among the "post-Zionist" scholars toward postmodernist (i.e., relativist) historiography and multicuturalist interpretations of the social reality in Israel. The very recent corpus focuses-as indeed does the 
public debate-on the role of academia in constructing a Zionist historiography and sociology. This new wave of scholars, who can be categorized as deconstructionist in methodology, aims at exposing the role played by the academic establishment in the nation-building process at the expense of freedom of thought and self-criticism. For example, these scholars, focusing on official texts, the content of museums, ceremonies, school curricula, and national emblems, have drawn attention to the way in which the dominant Ashkenazi group and its narrative has excised others from the national memory. ${ }^{21}$ Here, some of the scholars employed Edward Said's critique of Western Orientalism. The works exposed the sociological, anthropological, and historiographical discourses used in research on "Arabs"-whether Israeli Palestinians, Egyptians, or Sephardic Jews. ${ }^{22}$ The very grouping of Palestinians and oriental Jews as one subject matter, as has been done by Shlomo Swirski and Sammy Smooha, is contrary to everything Zionism and Zionist academia ever stood for. ${ }^{23}$

Others exposed the role played by Israeli academia in providing the scholarly basis for this act of repression and for serving as the scholarly tribunal that unconditionally had accepted the governmental axis of inclusion and exclusion. ${ }^{24}$ Of particular importance is the work of Uri Ram, who has examined how the Israeli sociological establishment analyzed Israeli society in the past. Ram showed how Zionist sociologists elaborated theories to fit notions such as the "ingathering of the exiles" and the "melting pot." These theories, which contradicted the reality of a heterogeneous multiethnic and multicultural society, were used to crush any opposition to the domineering Eastern European culture that might come from competing cultural directions, such as the one brought by Jews immigrating from Arab countries. ${ }^{25}$

The injection of moral and ethical questions into scholarly research on Zionism and Israel opened the way for a new examination of the Holocaust and its impact on Israeli society. This research so far has been of a more positivist nature, sending scholars back to the archives, but it has involved as well an ideological stance that has touched the most sensitive nerves of Jewish society. Particular attention is being paid to the way the local Jewish leadership behaved during the time of the Holocaust. In Tom Segev's The Seventh Million, for example, we find a local leadership, on the very eve of the Holocaust, interested in saving only Jews who were willing to immigrate or who were physically and mentally capable of contributing to the success of the community. In Idit Zartal's From Catastrophe to Power, we discover the lofty and dismissive attitude of the sabras toward the survivors and their plight, an attitude that was to leave deep scars in the souls of those who survived the Holocaust and got to Palestine. ${ }^{26}$

No less sensitive a subject to be dealt with recently is Israel as a militaristic society. Although there is no direct correspondence between militarism in the conventional European historical sense and the Israeli case,${ }^{27}$ the militaristic nature of Israeli society has two aspects: its actual influence on the country's conduct, and the way security considerations are exploited for the sake of discriminatory policies. 
Concerning the first, the scholars mainly are interested in explaining the present militaristic character of Israel as a product of its history. In order to do so, they had to rely heavily on positivist historians such as Benny Morris, who had mined the military archives of both 1948 and the 1950s to record accurately and painstakingly the aggression and offenses of the Israel Defense Forces. The "retaliation" policy of the 1950s (Israelis were brought up on the myth that Israel never initiates or provokes hostilities) is described by Morris as a brutal and aggressive form of Israeli expansionism. ${ }^{28}$ What one might call the "new political scientists," meanwhile, provided analyses in which Israel, far from being merely acted upon in the regional context, was very much an actor and initiator. Instability and conflict in the Middle East now were attributed not solely to "Arab radicalism" or "Arab intransigence," but to Israeli actions as well. ${ }^{29}$

The other side of the same coin has led bold young scholars to slaughter Israel's most sacred cow: "security above all." Here we meet the new political scientists who reject government explanations that security and national defense considerations were responsible for North African Jews being pushed to the geographical and social margins of the society, or for the imposition of an apartheid regime on the Palestinians who had remained in Israel. ${ }^{30}$ The policy was exposed as racist and nationalist. As mentioned before, most of these scholars drew parallels between the attitude toward Sephardic Jews and Palestinian Israelis. Edward Said's Orientalism influenced many of them to treat Israeli society as a whole as an "Orientalist" one. ${ }^{31}$

Another development is a growing interest not only in the historical but also in the present status of Palestinians in Israel. Critical works on these subjects have been written before; what is new is both the expansion of the critical assessment of Arab-Jewish relations in the state and the growing number of Palestinian academics in Israel willing to address these issues. In the past, given the general attitude toward Palestinians, it must have seemed safer to the few Palestinians in academia not to approach such problematic subjects as recent Palestinian history. (It is noteworthy that the number of Palestinians teaching in Israeli universities is still very small, no more than twenty staff members out of nine hundred). ${ }^{32}$

The recent wave has been even less acceptable to the mainstream academia than the positivist revisionism of the "new historians." Indeed, the findings of the latter, particularly (and in a way exclusively) of Benny Morris, eventually even were accepted by a growing number of historians. The neutral terminology he used (such as the 1948 war, expulsion, and so on) has been absorbed into the public discourse on 1948. His more general reference to Israel's original sin was less acceptable. ${ }^{33}$ Nonetheless, the exposure of Israeli academia to pluralism and multiculturalism is legitimizing an academic debate on the essence of Zionism, carrying permissible debate beyond the focus on the single (albeit crucial and formative in the country's history) chapter of 1948.

Still, every attempt to discuss the essence of Zionism-either by revisiting the early years of the movement or critically analyzing the society today-has been denounced as a typical intellectual exercise on the part of self-hating Jews in the 
service of the enemy. This position has been expressed with particular vehemence in the public debate in Israel on post-Zionism in recent years. ${ }^{34}$

It is noteworthy that the opposition has not come from the Right in Israel, which has a very limited representation in the Israeli academia, but from the Zionist Left. Although this Left accepts criticism of post-1967 Israel, the period 1882-67 is off limits. Critics of post-Zionism could be heard in the past voicing strong opposition to the continued Israeli occupation of the territories seized in the 1967 war. This protest, however, far from being anti-Zionist, was based on a strong commitment to consensual Zionist positions; it was this commitment that kept the Zionist Left from accepting the fundamental Palestinian positions on central questions such as the fate of the 1948 refugees or the future of Jerusalem as long as the PLO remained faithful to its strategic concepts. This position was institutionalized when the Peace Now movement came into being in 1978, first as a lobby for peace with Egypt and then making an impressive effort against Israel's Lebanon war during the Sabra and Shatila massacre in 1982. The movement remained active throughout the intifada, became idle and mute during the Rabin years, but has been given new life under the Netanyahu regime.

It should be stressed that the movement's reaction to the Lebanon war and later to the intifada did not deviate from the Zionist perception of reality. More specifically, Peace Now's criticism was and remains directed only against post1967 Israeli policy; its main concern has been this policy's effect on Israeli morale and morality. Many academics gravitated toward the movement, but their affiliation did not cause any change in the mainstream scholarly works on the past and present situation in Israel and Palestine. Still, it was, as we shall see, a beginning from which others, in particular film makers and playwrights, would continue and develop their own post-Zionist view of life in Israel. It was only when anti-Zionist positions, such as the ones held for years by the Communist party in Israel, were adopted by academics that fundamental changes occurred in the way Israelis perceived the "Arabs" or the "Palestinians," or indeed the whole Zionist project.

The presentation of the Palestinian and Israeli in the local Israeli media serves as an excellent example of the Peace Now predicament. As we shall show in the second part of this article, the press, paradoxically, conserves the old prejudices and images of Israel and the Palestinians while at the same time serving as the channel through which the findings and views critical of Zionist interpretations are conveyed to the public. It was through the press that the public became aware of the growing critique of Zionism among the different groups comprising the culture-producing community in Israel. Most of these groups have remained within the limited critique of Zionism typified by Peace Now, but they contributed to the decline of the Zionist myth and truth no less than their more radical and anti-Zionist colleagues inside and outside the local academia. 


\section{Notes}

1. The Israeli sociologist Uri Ram provided the most extensive explanation of this concept in his The Changing Agenda of Israeli Sociology: Theory, Ideology and Identity (New York: State University of New York Press, 1995).

2. A detailed description was provided in Ilan Pappé, "The New History of the 1948 War," Theory and Criticism, 3 (1993), pp. 95-114 [in Hebrew].

3. Yehoshua Porath, The Emergence of the Palestinian-Arab National Movement, 1918-1929 (London: Frank Cass, 1974) and The Palestinian Arab National Movement, 1929-1939 (London: Frank Cass, 1977).

4. See for instance Yoseph Nevo, "The Palestinians and the Jewish State, 1947-48" in We Were Like Dreamers, Y. Wallach, ed. (Tel Aviv: Masada, 1985) [in Hebrew] and recently Itamar Rabinovich's, The Road Not Taken: Early Arab Negotiations (New York and Oxford: Oxford University Press, 1991), which ignores the Palestinian side of the story altogether.

5. Moshe Shemesh, The Palestinian Entity, 1959-1974: Arab Politics and the PLO (London: Frank Cass, 1988).

6. Four major works were first mentioned in this wave: Simha Flapan, The Birth of Israel (New York: Pantheon, 1984); Benny Morris, The Birth of the Palestinian Refugee Problem, 1947-1949 (Cambridge: Cambridge University Press, 1988); Ilan Pappé, Britain and the ArabIsraeli Conflict, 1948-1951 (New York: Macmillan, 1988); and Avi Shlaim, Collusion Across the Jordan: King Abdullah, The Zionist Movement, and the Partition of Palestine (Oxford: Clarendon, 1988). To these one can add Uri Bar-Joseph, The Best of Enemies: Israel and Transjordan in the War of 1948 (London: Frank Cass, 1987); Michael J. Cohen, Palestine and the Great Powers, 1945-1948 (Princeton: Princeton University Press, 1982); and Tom Segev, 1949: The First Israelis (New York: Free Press, 1992).

7. Ilan Pappé, The Making of the Arab-Israeli Conflict, 1947-1951 (New York: I. B. Tauris, 1992), pp. 102-35.

8. Almost all the new historians mentioned in endnote 6 have dealt with this tacit understanding, referred to by Avi Shlaim as a "collusion."

\section{See Ilan Pappé, Britain.}

10. See Walid Khalidi, "Plan Dalet: Master Plan for the Conquest of Palestine," in Middle East Forum, November 1961 , reproduced with a new commentary in JPS 18, no. 1 (Autumn 1988), pp. 4-70.

11. See Morris, Refugees. For a discussion on the difference between the two narratives and my own position that accepts that there was a master plan, see Pappé, The Making, 203-43.

12. These claims are made by Morris and Pappé in particular.

13. Uri Ram represents this approach; see Uri Ram, ed., Israeli Society: Critical Perspectives (Tel Aviv: Brerot, 1993), introduction [in Hebrew].

14. Ibid.

15. Ibid., 18-25.

16. A notable example is Sami Smooha, Israel: Pluralism and Conflict (Berkeley: University of California Press, 1978) and Yonathan Shapira, "The Historical Origins of Israeli Democracy" in Israeli Democracy Under Stress, Ehud Sprinzak and Larry Diamond, eds. (Boulder: Lynne Rienner, 1993).

17. This approach is particularly evident in Anita Shapira, Visions in Conflict, (Tel Aviv: Am Oved, 1988) [in Hebrew].

18. See Uri Ram, "The Colonization Perspective in Israeli Sociology," in Journal of Historical Sociology 6, no. 3 (September 1993), pp. 327-50 and Gershon Shafir, Land, Labor and the Origins of the Israeli-Palestinian Conflict, 1882-1914 (Cambridge: Cambridge University Press, 1989).

19. Baruch Kimmerling, Zionism and Territory: The Socio-Territorial Dimensions of Zionist Politics (Berkeley: University of California Press, 1983), and Shafir, Land.

20. Moshe Lissak in an interview in Davar, 18 March 1994; and Yaakov Katz in an interview in Ha'Aretz, 18 November 1994.

21. On museums see Tamar Katriel, "Remaking Place: Cultural Production in an Israeli Pioneer Settlement Museum," History and Memory 5, no. 2 (Fall-Winter 1993), pp. 104-35; and Ariela Azoulay, "With Open Doors: Museums and History and the Israeli Public Space," Theory and 
Criticism, 4 (1993), pp. 79-96 [in Hebrew].

22. On Israeli Orientalism, see Azmi Beshara, "On the Question of the Palestinian Minority in Israel," Theory and Criticism, 3 (1993), pp. 7-21; Gil Eyal, "Between East and West: The Discourse on the Arab Village in Israel," Theory and Criticism, 3 (1993), pp. 39-56; and Dan Rabinowitz, "Oriental Nostalgia: The Transformation of the Palestinians into 'Israeli Arabs,"' Theory and Criticism, 4 (1993), pp. 141-52.

23. Smooha already had viewed these positions in the late 1970s (see Smooha, Israel), as did Sara Kazir and Shlomo Swirski in "Ashkenazim and Sephardim: The Making of Dependence," in Mahbarot le-Mehkar ve-Bikoret 1 (1978), pp. 21-59 [in Hebrew].

24. Many of the "new sociologists" have contributed in this vein to Ram, Israeli Sociology.

25. See Ram, Changing Agenda.

26. Tom Segev, The Seventh Million (New York: Hill and Wang, 1989); and Idit Zartal, From Catastrophe to Power (Tel Aviv: Keter, 1996) [In Hebrew it is called The Jews' Gold].

27. See Uri Ben-Eliezer, The Emergence of Israeli Militarism, 1936-1956 (Tel Aviv: Chrikover, 1995)

28. Benny Morris, Israel's Border Wars: Arab Infiltration, Israeli Retaliation, and the Countdown to the Suez War (Oxford: Clarendon, 1993).
29. These include Ben-Eliezer, Emergence; Shulamit Carmi and Henry Rosenfeld, "The Emergence of Nationalistic Militarism in Israel," International Journal of Politics, Culture and Society 3, no. 1 (1989), pp. 5-49; Avishai Erlich, "Israel: Conflict, War and Social Change, in The Sociology of War and Peace, Colin Creighton and Martin Shaw, eds. (London: Macmillan, 1987), pp. 121-43; and Baruch Kimmerling, "Patterns of Militarism in Israel," Archieve European Sociologie 34 (1993), pp. 196-223.

30. Yagil Levy, "A Militaristic Policy, Interethnic Relationship and Domestic Expansion of the State: Israel 1948-1956," Theory and Criticism, 8 (1996), pp. 203-24 [in Hebrew].

31. Ella Shohat, Israeli Cinema: East/ West and the Politics of Representation (Texas: University of Texas Press, 1989).

32. Among them Azmi Bishara, Aziz Faisal, Asad Ghanim, Majid al-Haj, Nadim Rawhana, Khail Rinnawi, Ahmad Saadi, and others in an ever-growing community.

33. See for instance "A Symposium on Post-Zionism," Ha'Aretz, 15 October 1995.

34. At one point a public debate was attended by over 700 people at Tel Aviv University in July 1994. See the condemnation by Shlomo Aharonson in "The New Historians and the Challenge of the Holocaust," Ha'Aretz, 24 June 1994. 